\title{
Śmierć w młodym polskim kinie. Strategie i reprezentacje zabijania
}

\begin{abstract}
Streszczenie
W ostatnich latach filmowcy średniego pokolenia chętnie pokazywali przemoc poprzez jej ujęcie gatunkowe: czy to w thrillerach (filmach o seryjnych zabójcach), czy filmach kryminalnych. Najmłodsze pokolenie filmowe - urodzone w latach osiemdziesiątych - spogląda na ten motyw z zupełnie innej perspektywy. Młodzi twórcy unikają konwencji gatunkowych, przełamując - estetycznie i fabularnie - dotychczas dominujący w rodzimej kinematografii obraz przemocy i stawiając przed nim nowe zadania. W artykule przyglądam się sposobom obrazowania śmierci w najmłodszym kinie, z zaznaczeniem filmowych i społecznych kontekstów oraz analizą ich funkcji. Przedstawiam reprezentacje zabijania w ramach trzech strategii: heroicznej atrakcyjności, arthouse’owej dosadności i generacyjnej diagnozy.

Heroiczną atrakcyjność opisuję na przykładzie dwóch filmów o powstaniu warszawskim - Miasto 44 (2014, J. Komasa) oraz Baczyński (2013, K. Piwowarski) - w których estetyzowana śmierć zostaje pokazana jako najwyższy model poświęcenia dla ojczyzny, a jednocześnie pełni rolę atrakcji. Na antypodach takiego obrazu figuruje strategia kina artystycznego, w której zabójstwo ukazane jest jako bezsensowny akt przemocy. Analizy tego motywu, estetycznie wzorowanego na konwencjach zachodniego kina arthouse’owego, dokonuję na przykładzie Placu zabaw (2016, B.M. Kowalski)
\end{abstract}

${ }^{1}$ Magdalena Urbańska, Wydział Zarządzania i Komunikacji Społecznej, Uniwersytet Jagielloński w Krakowie, Polska, e-mail: urbanska.magda@wp.pl, ORCID ID: https:// orcid.org/0000-0003-2961-1676. 
i Hardkor disko (2014, K. Skonieczny). Za pośrednictwem trzeciego sposobu pokazywania zabijania - występującego w: Obietnicy (2014, A. Kazejak), Reakcji łańcuchowej (2017, J. Pączek) i Bejbi Blues (2012, K. Rosłaniec) - twórcy próbują rysować obyczajowy i psychologiczny portret danej generacji. W artykule szczegółowo analizuję powyższe strategie ukazywania śmierci i reprezentacje obrazów przemocy w najnowszej kinematografii, aby ukazać je jako odmienne na tle dotychczasowych tradycji kina polskiego.

\title{
Słowa kluczowe:
}

śmierć, zabijanie, morderstwo, kino polskie, pokolenie, powstanie warszawskie, arthouse

\begin{abstract}
In recent years, middle-aged filmmakers have been willing to show violence through its genre-based approach: in thrillers (movies about serial killers) or crime movies. The youngest generation of filmmakers - born in the eighties - looks at this motif from a completely different perspective. Young directors avoid genre conventions by breaking down - both aesthetically and dramatically - the picture of violence that dominates in their national cinematography and by then assigning it new functions. In the article I describe the ways of depicting death in the youngest cinema, focusing on their movies and social contexts and analysing their functions. I present portrayals of killing within three strategies: heroic attractiveness, arthouse explicitness and generational diagnosis.

I describe the strategy of heroic attractiveness on the basis of two films about the Warsaw Uprising - Miasto 44 (2014, J. Komasa) and Baczyński (2013, K. Piwowarski) - in which the aesthetic death is shown as the greatest sacrifice for the fatherland/for your country/, and at the same time serves as an attraction. On the opposite end of the spectrum there is a strategy of artistic cinema, in which murder is shown as a senseless act of violence. I analyze this motif, aesthetically modeled on the conventions of western arthouse cinema, based on two examples: Plac zabaw (2016, B.M. Kowalski) and Hardkor disko (2014, K. Skonieczny). By the third strategy of killing - appearing in the Obietnica (2014, A. Kazejak), Reakcja łańcuchowa (2017, J. Pączek) and Bejbi Blues (2012, K. Rosłaniec) - the creators try to draw the moral and psychological portrait of depicted generation. In the article, I analyze the foregoing strategies of depicting death and images of violence in the latest cinematography to show them as different from the current traditions of Polish cinema.
\end{abstract}

\section{Keywords:}

death, killing, murder, Polish cinema, generation, Warsaw Uprising, arthouse 
Szczyt popularności przemocy w polskiej kinematografii po transformacji ustrojowej związany był z kinem bandyckim lat 90. Nastąpiło wówczas przeorientowanie kina, zgodne z podejściem „mitu przełomu”: „dość problematyki narodowej, dość historii, która w rodzimym wydaniu i tak staje się martyrologią; skoro publiczność wybiera kino amerykańskie, to i polscy filmowcy będą dla niej teraz robić takie kino.” (Lubelski, 2015, s. 624) Przez dekadę tryumfy święciły filmy wykorzystujące reguły amerykańskiego filmu policyjnego oraz - choć już w mniejszym stopniu - ich pastisze. Formuła filmów bandyckich wyczerpała się wraz z krzepnięciem rodzimej demokracji i de facto zniknęła z ekranów na kolejne lata, gdy kino skupiło się przede wszystkim na kwestiach pamięci narodowej oraz rejestrowania zmieniającego się świata, zaś wśród filmów popularnych zaczęła dominować komedia. Tymczasem od kilku lat reżyserzy średniego pokolenia znów sięgają po gatunkowe uzasadnienie przemocy: w thrillerach, często dotykających tematu seryjnych morderców (np. Czerwony pająk [2015, M. Koszałka], Jestem mordercq [2016, M. Pieprzyca], Amok [2017, K. Adamik], Ach, śpij, kochanie [2017, K. Lang]), lub w kinie kryminalnym (m.in. Jeziorak [2014, M. Otłowski], Ziarno prawdy [2015, B. Lankosz] czy Sługi boże [2016, M. Gawryś]). Wysyp tego rodzaju kina wspierała z pewnością ogromna popularność książek kryminalnych oraz seriali - tak zagranicznych, jak i polskich (m.in. Belfer, Pakt czy Wataha). Co ciekawe, wśród twórców powyższych gatunków brakuje reżyserów najmłodszego pokolenia, którzy nie unikają w swojej kinematografii pokazywania okrucieństwa, lecz spoglądają na ten motyw z zupełnie innej perspektywy. Motyw zabijania u najmłodszych reżyserów - przede wszystkim roczników osiemdziesiątych - pojawia się w ostatnich latach nad wyraz często, nierzadko przełamując - estetycznie i fabularnie - dotychczas dominujący w rodzimej kinematografii obraz przemocy i stawiając przed nim nowe zadania. Warto przyjrzeć się sposobom obrazowania śmierci w najmłodszym kinie, jako że odnosi się ona do nowych społecznych wyobrażeń i kontekstów, gra z wyobrażeniami widza i każdorazowo pełni odmienną funkcję. Reprezentacje zabijania można podzielić na trzy różne strategie: heroicznej atrakcyjności, arthouse’owej dosadności i generacyjnej diagnozy.

\section{HEROICZNA ATRAKCYJNOŚĆ}

Jednym z największych na nowo odkrytych obszarów tematycznych, jakie pojawiły się w polskiej kinematografii XXI wieku, jest rozkwit kina powstańczego (zob. Szczekała, 2014). W ciągu trzech lat pojawiło się aż pięć filmów o Powstaniu Warszawskim: Był sobie dzieciak... (2013, L. Wosiewicz), Sierpniowe niebo. 63 
dni chwały (2013, I. Dobrowolski), Baczyński (2013, K. Piwowarski), Powstanie Warszawskie (2014, prod. Muzeum Powstania Warszawskiego) i Miasto 44 (2014, J. Komasa), choć wcześniej przez całe lata nie ukazało się na ten temat żadne dzieło. Powstanie, jak pisał Marcin Napiórkowski, „dysponuje dziś olbrzymim potencjałem jako generator sensu - katalizator nastrojów, punkt orientacyjny, narzędzie zdolne zarówno do budowania wspólnoty, jak i wykluczania obcych. Skomplikowana historia pamięci przekuła powstanie w potężny mit, zdolny inspirować, porywać i napełniać dumą” (Napiórkowski, 2016, s. 15). Na uboczu pozostawiając zasadność podjęcia w 1944 roku narodowego zrywu, niestanowiącą bezpośredniego pola zainteresowań tego artykułu, warto przyjrzeć się, jakim „generatorem sensu” jest śmierć w powstańczej walce. Innymi słowy: czy sposób umierania postaci może nam coś powiedzieć o rodzaju wspólnoty, jaki projektują młodzi twórcy dla narodowej publiczności. Spośród wspomnianych filmów dwa tytuły można zaliczyć do dzieł stworzonych przez młodych twórców, których spojrzenie na śmiercionośne wydarzenie historyczne można potraktować jako perspektywę pokoleniową: Miasto 44 i Baczyński. W pierwszym z nich Jan Komasa (rocznik 1981) stworzył ciekawy przykład nowej stylistyki kina historycznego na gruncie polskiej kinematografii, doprowadzając spektakularność dzieła do ekstremum. Nie opiera się ono na przedstawieniu faktograficznie udokumentowanych losów świadków czy uczestników zdarzeń (choć faktograficzna zgodność i - jak wiemy po kampanii informacyjnej filmu² - wiarygodność zostały zachowane), ale na atrakcyjnej, wręcz blockbusterowej formie. Przez to podnosi problematykę realistycznej konwencji oraz ustanawia proces fizycznej identyfikacji jako mechanizm emocjonalnego zaangażowania widza (Urbańska, 2017). Zupełnie inaczej, choć także na pierwszym miejscu stawiając oryginalność formalną, na temat Powstania Warszawskiego spogląda Kordian Piwowarski (rocznik 1978, którego niewielki dorobek filmowy, a także włączenie w dzieło elementu nowej kultury - slamu, pozwalają również sytuować go wśród najmłodszego pokolenia twórców). Wybiera on na bohatera wrażliwego i skromnego poetę i mimo że za pomocą recytacji wierszy wprowadza nastrój zadumy i nostalgii, to także nie opiera się formalnej ekstrawagancji. U jednego i drugiego twórcy obecności śmierci zaświadcza zaś o wielkości historii, stając się rdzeniem - kulturowym, historycznym i społecznym - na którym wyrastają dzisiejsze narodowe wartości.

2 Dystrybutor Kino Świat zamieścił w internecie m.in. film, w którym uczestnicy powstania warszawskiego wypowiadali się na temat dzieła Komasy, potwierdzając: „Tak to powstanie wyglądało” (zob. https://www.youtube.com/watch?v=fBAEoOFM1nw\&t=49s). 


\section{Performatywność śmierci}

U obu reżyserów śmierć głównego bohatera nie jest puentą ich historii, ale immanentnym stanem, z którym muszą się borykać podczas życia - niespełnionego na tyle, na ile dla Polaków wówczas było egzystowanie bez pełnej wolności narodowej. Stefanowi z Miasta 44 - na płaszczyźnie fabularnej - udaje się przeżyć powstanie, choć w większości jest jego niemym świadkiem, figurą, która przyjmuje dwuznaczny status: na pograniczu życia i śmierci. „Wolność? Zasady? Niepodległość? Nie, o tym wcale nie myślą. Uruchamiają się w nich podstawowe instynkty, wszechobecna śmierć rozpuszcza wszystko, poza jednym: wręcz zwierzęcą chęcią przeżycia” (Socha, 2017) - pisze Jakub Socha, analizując dzieło Komasy. W wielu scenach śmierć jest obecna „na wyciągnięcie ręki” (świszczące obok bohaterów strzały, umierający wokół ludzie), występują jej artefakty i atrybuty (lejąca się krew, deszcz ludzkich szczątków), ale nie dotyka ona bezpośrednio głównych postaci. Stefan zostaje ranny w trakcie ostrzelania cmentarza, zaś rwany montaż - oddający chaos i natarczywość walk pokazuje nam go następnie jako zupełnie nieprzytomnego pół-człowieka. Kolejne sceny, zwłaszcza słynny obraz w kanałach, gdzie bohater funkcjonuje jako przeniesiona z horroru figura zombie, potwierdzają, że bohater egzystuje jako „żywy umarły.” Figura ta z jednej strony poddaje refleksji charakter działań wojennych (ich trauma i piętno sprawiają, że „nikt żywy nie wyszedł z powstania”), z drugiej - (auto)tematyzuje sam wątek kina, w którym bohater zawsze znajduje się na granicy pomiędzy życiem a śmiercią, pomiędzy człowiekiem a jego widmem (Janion, 1991). Jeszcze silniejsze metafilmowe odwołania, budujące obraz walk jako „występu”, przynosi scena rozstrzelania matki i brata podglądana przez Stefana przez okno, przez które wcześniej rodzina obserwowała jego występy. Zarówno wykonywany taniec, jak i rozstrzelanie (w trakcie którego matka aktorka ma świadomość bycia oglądaną przez syna, więc „odgrywa” swoją rolę, by go uspokoić) odwołują się nieuchronnie do połączonych ze śmiercią autoreferencyjnych nawiązań w obrębie samego medium. Warszawa Komasy przeniknięta jest śmiercią. Jej nieustająca potencjalność- stanowi o podniosłości podjętej walki, z kolei performatywność - ciągłe jej stwarzanie - o sprawczości, dzięki której przetrwanie Stefana staje się symbolem dalszego istnienia narodu.

U Piwowarskiego tym, co świadczy o nieśmiertelności bohatera - mimo drastycznego obrazu pozbawienia go życia - jest jego poezja. Baczyński osadza się na przewrotnym pomyśle: sceny fabularne dotyczące poety są przeplatane z quasi-reportażem ze spotkania poezji slamerskiej. Nie ma tu, jak w tradycyjnym slamie, elementu pojedynku, jest tylko prezentacja poezji autora - forma bardziej teatralna niż performatywna, jaką na co dzień przybiera ta dyscyplina (Kołodziej, 
2013). Mimo to poprzez na-żywość (liveness) jego poezji podważona zostaje śmierć bohatera. Instytucjonalizacja twórczości (bliżej jej do wieczoru poetyckiego niż slamu, charakteryzującego się prezentacją oryginalnej twórczości i żywą reakcją widowni) oddaje wzniosłość i konstytutywność okoliczności, w których powstała. Ma to uwypuklić pozytywne wartości podjętych czynów, co widać przez zbliżenia na wzruszone i zasłuchane twarze publiczności. Z jednej strony stosunek twórców do „generatora sensu”, jakim jest dziś Powstanie Warszawskie, można zapewne odczytywać na poziomie całości fabuły, z drugiej zaś - sama potencjalność śmierci, z jednoczesnym podważeniem jej jednoznacznego statusu, ukazuje ją jako najwyższy model poświęcenia dla ojczyzny, w którym nie liczą się realne konsekwencje.

\section{Śmierć jako atrakcja}

Rafał Syska, analizując przemoc w filmie, pisze: „Jedną z najważniejszych artystycznie (i również psychologicznie) konsekwencji ewolucji filmowego okrucieństwa stało się traktowanie aktów przemocy w oparciu o kategorię atrakcji - efektownej, a zarazem wydzielonej w diegezie filmu sceny. Uzasadniana rozwojem fabuły, ale przesadnie rozbudowana i naznaczona odmienną estetyką, rozpoczęła egzystencję niezależną wobec całości dzieła. Stając się numerem (violent number), przerywała linearną fabułę, mimo dynamizmu wstrzymywała akcję i zawieszała rozwój intrygi” (Syska, 2003, s. 93). Zarówno Miasto 44, jak i Baczyński doprowadzają tę tendencję do ekstremum. W filmie Komasy tak rozumiana śmierć przenika całość obrazu także na poziomie estetycznym - staje się ona elementem świadczącym o blockbusterowym rodowodzie realizacji, co rusz przerywając obraz na rzecz czystej kontemplacji oraz spychając narrację na drugi plan. U Piwowarskiego śmierć głównego bohatera stanowi zaś efekciarską etiudę o odmiennym tempie, nastroju, muzyce, estetyzującą śmierć i będącą zachwytem nad jej fenomenem.

W Mieście 44 młody reżyser odważnie sięga po środki filmowe przynależne blockbusterowi z jego naciskiem na spektakularność przedstawiania, produkuje estetyczny nadmiar, używa efektów specjalnych nie tylko po to, by oddać realizm scen batalistycznych czy odzwierciedlić intensywność walki, ale by uatrakcyjnić obraz. Elementy spektakularne jednocześnie umacniają więź z przyzwyczajonym do nadmiaru medialnych bodźców i nadprodukcji efektów młodym odbiorcą. Atrakcja rodzi się poprzez czytelne dla widzów odwołania do strategii i praktyk przynależnych innym gatunkom filmowym (jak melodramat czy musical), innym mediom (jak gra komputerowa), a nawet przez samo autotematyczne odwołanie 
do samego kina. W ten sposób przemoc zostaje ujęta w ramy spektaklu (Chapman, 2008).

W Mieście 44 użyte zostają wszystkie trzy perspektywy, jakie może zastosować twórca w ramach identyfikacji z widzem: strategia świadka, mordercy, ofiary (Syska, 2003, s. 93). Główny bohater, Stefan, staje się po kolei każdą z tych figur, a ciągła zmiana perspektyw świadczy także o atrakcyjności widowiska. „Stosowane przez reżyserów voyeurystyczne chwyty, wzmagając identyfikację publiczności z bohaterem, potęgują również odczucia zadającej lub otrzymującej ciosy postaci. Ofiarą stworzonego w filmie aktu przemocy powinien stać się również odbiorca. (...) Film powinien dzielić odczucia fizyczne i psychiczne bohatera, zmagać się z cierpieniem i strachem, uświadamiać sobie istnienie destrukcyjnych instynktów" (Syska, 2003, s. 19). W Mieście 44 „zwrot do widza” widać szczególnie poprzez subiektywizację kamery. Ujęcia z punktu widzenia głównego bohatera (tzw. POV - point-of-view) najczęściej zostają wykorzystane w scenach strzelanin - stylizacja na grę typu first-person shooter sprawia, że widz ma wrażenie uczestniczenia w komputerowej symulacji. W takiej perspektywie nie tylko ,jest zauważony”, co zarysowuje relację z twórcą, ale staje się podmiotem obrazu: nie tyle utożsamia się z bohaterem, co sam się nim staje.

W Baczyńskim śmierć została również potraktowana jako atrakcja. Scena umierania jest najważniejszą częścią fabuły. Wyróżnia się patetycznym nastrojem, potęgowanym przez wzniosłą muzykę i puentującą scenę recytację wiersza poety (Noc zielona była...). Jasny snop światła padający na bohatera, nagła cisza w momencie zestrzelenia i powolny, pokazywany niemal klatka po klatce upadek stanowią wręcz stereotypowo potraktowaną wizualizację filmowej śmierci. Estetyka slow-motion daje widzowi czas, aby mógł ową śmierć kontemplować, kreując jednocześnie jej bohaterski ceremoniał. Tutaj również spektakularne widowisko wystawia śmierć na bliską obserwację. Strategia heroicznej atrakcyjności próbuje wywołać w widzu świadomość wzniosłości śmierci - albo poprzez bezpośredni zwrot do widza, jak w filmie Komasy, lub przez wystawienie jej na patetyczną odbiorczą gloryfikację, jak w Baczyńskim.

\section{ARTHOUSE'OWA DOSADNOŚĆ}

Motyw zabijania obecny jest także w polskim kinie autorskim, choć jego reprezentacja zostaje pokazana z zupełnie innej perspektywy - przede wszystkim śmierć pojawia się bez zapowiedzi, wentylu bezpieczeństwa, bez żadnego kontekstu, za pośrednictwem którego widz może ją sobie racjonalnie wytłumaczyć. Jest niema, 
drastyczna i słabo umotywowana. Przykładem takiego obrazowania przemocy są filmy Plac zabaw (2016) Bartosza M. Kowalskiego (rocznik 1984) oraz Hardkor disko (2014) Krzysztofa Skoniecznego (rocznik 1983) - oba zrealizowane w kluczu kina arthouse'owego, z niespieszną narracją i nieschematycznymi postaciami wymykającymi się jednoznacznej ocenie oraz surowemu, obiektywnemu spojrzeniu twórcy.

\section{Przemocowy everyman}

Tym, co najbardziej fascynowało widzów w postaci Hannibala Lectera, była nieprzystawalność jego osoby - wykształcenia, intelektu, manier i zachowania - do stereotypowych wyobrażeń o mordercy. Przemoc jest podświadomie akceptowalna, gdy aprobujemy zachowania osób, które jej używają (Syska, 2003, s. 32). Zarówno w Placu zabaw oraz w Hardkor disco zostaje zbudowany dwuznaczny obraz bohaterów, choć widz początkowo darzy ich pozytywnymi emocjami - sympatią i współczuciem. Tym większym zaskoczeniem i szokiem są popełnione przez nich zbrodnie - wyrachowane i zdystansowane. W filmie Skoniecznego pewnego rodzaju tarczą ochronną jest pokazanie temperamentu głównego bohatera, Marcina, symbolicznie agresywne gesty (zakładanie kaptura, zerkanie wprost w kamerę, wyjmowanie noża), po których możemy domyślać się zdolności chłopaka do przemocy. Gdy jednak następuje zbrodnia, widz - niezależnie od owych podprowadzających tropów - jest zszokowany jej nieuzasadnioną obecnością. Pewnego rodzaju pomniejszeniem zaskoczenia czy bezbronności odbiorcy jest zasugerowanie historii zemsty - ten wątek jednak świadomie zostanie niewyjaśniony, ledwie zarysowany, by odbiorca nie mógł znaleźć komfortu w jednoznacznym motywie. U Kowalskiego w Placu zabaw nieprzystawalności działania do bohaterów spotęgowane jest także przez ich młodzieńczy wiek.

Nie wiemy do końca, kim jest Marcin z Hardkor disko. Jest nonszalancki, ale uprzejmy, taktowny, wie, jak się zachować, potrafi się bawić i zawierać nowe znajomości. Jest może nieco tylko zbyt milczący, tajemniczy, a nieraz zbyt impulsywny, ale w gruncie rzeczy jego wybuchy są zawsze adekwatne do sytuacji. Gabrysia, Szymek i Czarek z Placu zabaw pochodzą z trzech różnych warstw społecznych: od bogatego domu po rodzinę niemal patologiczną. W filmie Kowalskiego portrety młodych bohaterów są rysowane subtelnie, wielowymiarowo, przekonująco. To dzieciaki jak wiele innych: żywotne, z kompleksami, problemami, mające rozterki i sympatie. Trudno zatem jednoznacznie określić przyczyny przemocowych zajść, które pojawiają się bez zapowiedzi. Młody Szymek zajmuje się sparaliżowanym ojcem i pokornie zmaga się z trudami codzienności. W pewnym momencie - zupełnie niespodziewanie - daje upust pulsującym w nim emocjom i uderza ojca w twarz. 
Czarek, choć z zadatkami na łobuza, zostaje pokazany jako bezsilny chłopiec, stłamszony w domowym otoczeniu, niemający własnego miejsca - zarówno pokoju, jak i przestrzeni wewnętrznej na skumulowanie i uciszenie targających nim emocji, przez co budzi współczucie. Jego życiową złość widz usprawiedliwia, mając przekonanie o niejednoznaczności chłopca. Rzeczywistość, w której żyją bohaterowie, jest przygnębiająca, ale wiarygodna. To właśnie owa normalność, wręcz przeciętność bohaterów i ich codziennych sytuacji przeraża najbardziej, bowiem za jej pomocą widz uświadamia sobie realność występowania finałowej sytuacji przemocy. Drastyczne zabójstwo niewinnego chłopca mogłoby rozegrać się niemalże po sąsiedzku.

Nie inaczej jest w Hardkor disko, choć w tym filmie przenosimy się w zupełnie inne społeczne rejony - wielkomiejskiego życia nowobogackiej części społeczeństwa. Skonieczny wrzuca w jej środek figurę Marcina jako obcego, wysłannika z zewnątrz, który niczym mężczyzna z Teorematu (Pasolini, 1968) rozsadza od środka zastane relacje. Schematyzm i stereotypowość, z jakimi twórca pokazuje klasę średnią (mimo wszystko budzącą sympatię) i wcale nieodstającą tak od reszty figurę ludzkiego demona, sprawiają, że śmierć mniej nami wstrząsa, niż mogłaby w tej sytuacji - choć jest równie niezapowiedziana i nieprzewidywalna.

\section{Perspektywa świadka}

Najważniejsze we wspomnianych filmach o arthouse'owej proweniencji jest pozbawienie przemocy i zabijania bezpiecznika w postaci psychologicznej czy narracyjnej motywacji, gatunkowej konwencji czy nawet ironicznej gry. „W klasycznym kinie śmierć obudowana jest przygotowawczymi ceremoniami, uprzedzającymi dramatyczne zdarzenie rytuałem: skradaniem się do ofiary, zbliżeniem na zaciskający się na cynglu palec, usprawiedliwiającą morderstwo uprzednią konfrontacją. Skierowane wobec widza "pojednawcze« gesty oswajają go z mającym nastąpić za chwilę szokującym zdarzeniem, przygotowują emocjonalnie i fizycznie, zamykając tym samym śmierć w ułatwiających percepcję schematach dramaturgicznych” (Syska, 2003, s. 160). W opisywanych filmach brutalna śmierć pojawia się nagle, niespodziewanie, wręcz - wydawałoby się - niezgodnie z logiką fabuły. Do czasu bestialskiego mordu rozwój zdarzeń zdaje się kierować widza w stronę zupełnie innej kulminacji. Moment zabójstwa nie jest emocjonalny czy gwałtowny, lecz toczy się w rytmie dotychczasowej narracji. W obu filmach nie ma przyozdabiania go w wyszukane figury stylistyczne czy metafory, a przy tym żaden gest nie dzieje się poza kadrem, zostaje chłodno zarejestrowany w czasie rzeczywistym.

Na ten drastyczny akt agresji patrzymy z boku, z pozycji bezstronnego, neutralnego świadka. Zarówno w Placu zabaw, jak i w Hardkor disko wstrząs odbiorczy 
odbywa się na dwóch płaszczyznach: przerażenia realnością sytuacji oraz szoku wywołanego zmianą zachowania bohaterów. Nasza bezradność w starciu z czystym i nieuzasadnionym okrucieństwem rodzi poczucie bezsilności. W jednym i drugim dziele kamera w sposób zdystansowany i neutralny obserwuje ciąg ciosów, kolejne czynności, czasochłonne tortury. U Skoniecznego obserwujemy każdy element działania Marcina, jakby popełniał wcześniej przygotowany rytuał - bez emocji, paniki, pośpiechu. Podkreślony zostaje wysiłek, jakiego wymaga uduszenie dorosłego człowieka. Kowalski przyjmuje oddaloną perspektywę, długie ujęcie pozbawione jest elips, ruchu kamery i zmiany punktów widzenia, które dawałyby widzowi jakikolwiek oddech czy możliwość wytchnienia. Konfrontacja nieruchomej kamery z pełną dramatyzmu sceną ma wywołać w widzu poczucie dyskomfortu. Chwyt, charakterystyczny dla współczesnego kina arthouse’owego, jest także formą odmowy estetyzacji scen przemocy.

W strategii arthouse’owej dosadności i drastyczności aktom przemocy dodaje użycie banalnych narzędzi, a przede wszystkim ludzkiej siły, która odsłania wielkość wysiłku, na jaki trzeba się zdobyć, aby zabić człowieka. Co ciekawe, w obu filmach taki „brudny” sposób zabijania nie wynika z wybuchu złości czy innych emocji, które sugerowałyby, że zbrodnia została popełniona w afekcie. Mechaniczne, popełnione z zimną krwią zabójstwa przerażają głównie za sprawą surowego obiektywizmu i zaburzenia gatunkowych oczekiwań względem sposobów reprezentacji śmierci.

\section{GENERACYJNA DIAGNOZA}

Ostatnią ze strategii reprezentacji zabijania w najmłodszym kinie polskim jest generacyjna diagnoza. W tych filmach śmierć pojawia się niejako przy okazji nie stanowi punktu kulminacyjnego, nie jest bezpośrednim tematem dzieł, choć występuje jako ważny element fabularny. Obrazy reprezentatywne dla takiej formy ukazania śmierci to: Obietnica (2014) Anny Kazejak (rocznik 1979), Reakcja łańcuchowa (2016) Jakuba Pączka (rocznik 1984), a także Bejbi blues (2012) Katarzyny Rosłaniec (rocznik 1980). Obraz zabójstwa jest w nich jednym z narzędzi opisania współczesnego świata i rzeczywistości, w której funkcjonują młodzi ludzie. Co dla tych filmów znaczące, zabójstwo za każdym razem odbywa się poza ekranem, nie mamy do niego bezpośredniego dostępu, oglądamy zaś tylko jego społeczne i psychiczne skutki dla bohaterów. Te (bez)emocjonalne reakcje na same zbrodnie są zresztą najbardziej wstrząsające dla widzów. 


\section{Zabójstwo na chłodno}

W Obietnicy kilkunastoletnia Lila, dziewczyna Janka, namawia go, by ten „usunął” koleżankę, o którą - po zdradzie chłopaka - jest zazdrosna. W niewyjaśnionych okolicznościach ginie Kasia, była dziewczyna Adama z Reakcji łańcuchowej. Natalia z Bejbi blues chowa swoje dziecko do skrytki na dworcu, by mieć czas dla samej siebie. Choć zamiary każdego z bohaterów są różne - nieraz śmierć jest intencjonalna, nieraz zdarza się przez przypadek - charakterystyczna jest reakcja postaci na wydarzenia. Żaden z bohaterów de facto nie ma wyrzutów sumienia, kalkuluje na chłodno swoje postępowanie, a nawet jeśli zdaje sobie sprawę z popełnionego czynu, to nie na tyle, by uniemożliwiło to jego kolejne moralnie dwuznaczne zachowania (Lila nie chce się przyznać do winy, Adam namawia dziewczynę do kłamstwa, zaś Natalia szybko decyduje się na kolejne dziecko). Nie jest to kwestia niepogłębionej psychologizacji bohaterów, lecz świadoma konstrukcja postaci, po których reakcji na śmierć można równie wiele powiedzieć, a nawet więcej niż po samym popełnionym czynie.

Twórcy ukazując brak wyrzutów sumienia i głębszych emocjonalnych skutków dokonanych czynów - częściej targa nimi strach przed konsekwencjami czy złość, że zbrodnia została wykryta, portretują pokolenie, które z zimnym dystansem przygląda się rozczarowującej rzeczywistości. W filmie Jakuba Pączka naiwne tłumaczenie Adama i błahość powodów, dla których popełnia zbrodnię, obrazują życiową pustkę, brak wyższych wartości, ale i prób buntu. Popełnienie zbrodni nie jest desperacją, ale de facto rezygnacją z walki o siebie, z wyboru indywidualnej ścieżki życia, nadania sobie samemu znaczenia. Przewrotność tego postępowania polega na tym, że - podobnie jak w Obietnicy - każdy z bohaterów jest na co dzień emocjonalnie niestabilny, a jednocześnie posiada zupełnie zimną świadomość samotności, braku znaczenia i społecznej alienacji. W tym świecie nie ma miejsca na bliskość, więcej jest w nim traumy i złości (w relacjach miłosnych) czy zimnej kalkulacji zysków (w relacjach rodzinnych). Prawdziwe emocje zastąpiły ich fantazmaty, a śmierć stała się kolejnym bodźcem do osiągnięcia wewnętrznego spokoju. Bez głębszego sensu czy nadania jej dodatkowego znaczenia symbolicznego.

Skoro śmierć nie stanowi większego wewnętrznego problemu dla bohaterów (wyjątkiem jest Janek z Obietnicy, który reaguje paniką i histerią po zamordowaniu koleżanki, jednak stanowi on właściwie postać drugoplanową, podczas gdy na pierwszy plan wysuwa się temat zobojętnienia Lili), nie zostaje ona pokazana, zdarza się jakby mimochodem - nie ma fizycznego wymiaru. W Reakcji łańcuchowej widzimy tylko zobrazowane senne wizje topiącego się ciała. W Bejbi blues - obserwujemy przez chwilę - zrozpaczoną Natalię, która wyjmuje ze skrytki 
(niewidoczne dla odbiorcy) martwe dziecko, a w Obietnicy o znalezieniu ciała dowiadujemy się z telewizji. Media są zresztą istotnym tematem wszystkich dzieł, np. skonfrontowanie w filmie Kazejak telewizji i internetu świetnie odzwierciedla rozdźwięk między reporterskimi, zdystansowanymi relacjami a emocjonalną, rozhisteryzowaną komunikacją nastolatków, zderzając zewnętrzny świat dorosłych z kompletnie nieprzystającym do niego uniwersum wartości młodych ludzi.

\section{Pokolenie rezygnacji}

Najistotniejszą funkcją opisywanej strategii jest ukazanie postaci jako reprezentantów danego pokolenia. Młodzi ludzie wyrastają z otaczającej ich rzeczywistości, są silnie zakorzenieni w realnym wymiarze społecznym - i to on stanowi nadrzędny temat dzieł, mających wręcz charakter manifestów. Bohaterowie filmu Pączka to dzisiejsi trzydziestolatkowie (dla których wybuch w Czarnobylu funkcjonuje jako przeżycie pokoleniowe) przesiąknięci rezygnacją, świadomi tego, że bunt nie jest już możliwy, bez sił, by podjąć walkę o zmianę zastanej rzeczywistości. Tło społeczne jest równie istotne w Obietnicy, która staje się diagnozą społecznej alienacji, nieumiejętność zbudowania międzypokoleniowej więzi i emocjonalnej pustki, jaka dotyka współczesne pokolenie nastolatków. Z kolei Bejbi blues to obyczajowy portret dwudziestolatków, ukazujący problem macierzyństwa (zbyt) młodych dziewczyn, dla których dziecko jest fanaberią, gadżetem uzupełniającym zestaw ich materialnych zachcianek. W filmach jak w lustrze odbijają się społeczne problemy całych pokoleń i bolączki młodych ludzi, których twórcy chcą sportretować, ale i zrozumieć.

Jeśli nadrzędnym celem filmów, w których młodzi zabijają, jest generacyjna diagnoza, to śmierć stanowi tu symboliczne uwypuklenie pulsującej w nich agresji, nienawiści, bezradności i niemocy. Przemoc nie jest skutkiem afektu czy niepanowania nad emocjami, wręcz przeciwnie - bohaterów cechuje wysoka samoświadomość, przejawiająca się w chłodnej (auto)analizie i skupieniu się na sobie. Filmy przynależące do tej strategii przyglądają się dzisiejszej młodzieży, tworząc uogólniony portret pokolenia - jednolitych grup społecznych. W żadnym dziele główny bohater nie wywołuje odbiorczej sympatii, częściej budzi współczucie czy rozdrażnienie. Ciekawe, że - być może poza ciążą nastolatek, która jednak nie jest przedstawiony jako szerszy problem społeczny - nie ma w nich publicystycznego zacięcia. Twórcy rezygnują z jednoznacznej, radykalnej diagnozy rzeczywistości społecznej, obrazu buntu (tak charakterystycznego dla pokoleniowych manifestów) czy nawet krytycznej oceny. Nie dają odpowiedzi, ale też nie stawiają pytań. W swojej pesymistycznej rezygnacji mają sporo z cech portretowanych bohaterów. 
Charakterystyczne dla opisywanych dzieł są postaci dominujących kobiet. O skomplikowanej emocjonalnej relacji Lili z Jankiem w Obietnicy dowiadujemy się ze wspominanej awantury, w której dziewczyna wybija partnerowi zęba w przypływie agresji. Właściwie do samego końca manipuluje, zwodzi, nakazuje i wpuszcza chłopaka w emocjonalny labirynt, z którego Janek nie potrafi znaleźć wyjścia. Nastolatek jest kruchy, płaczliwy i gotowy zabić, byle tylko Lila do niego wróciła. W Baby blues wszystkie postaci - z dorosłymi włącznie - są niedojrzałe, choć emocjonalna dominacja kobiet nad mężczyznami jest bardzo widoczna. Partner Natalii sam jest jeszcze dzieckiem, które nad opiekę nad synem przedkłada jazdę na deskorolce, zaś jego rodzice to typ Dulskich: dokazująca matka i milczący ojciec. O krok dalej idzie Pączek w Reakcji łańcuchowej, w której nie tylko Marta - dziewczyna Adama okazuje się najsilniejszą postacią, ale i portret matki jako kobiety sukcesu, owładniętej potrzebą perfekcji i poklasku, jest wręcz stereotypowo wyolbrzymiony. Żeńskie postaci w filmach generacyjnej diagnozy odwołują się do współczesnej figury femme fatale - i nawet jeśli to mężczyzna dokonuje zbrodni, częścią winy obarcza się silne, zdeterminowane kobiety.

$* * *$

Motyw zabijania nie tylko występuje coraz częściej we współczesnych polskich filmach najmłodszego pokolenia, ale pełni w nim inne niż dotychczas funkcje. Podczas gdy śmierć w polskim kinie wojennym często miała na celu heroizację bohaterów, nie odnosiła się dotąd aż w takim wymiarze do atrakcyjnej wizualności. To widowiskowość śmierci, nie zaś psychologiczny portret postaci, stanowi o naszym podziwie dla bohaterów. Na pewno też nie ich waleczność jest podstawą gloryfikacji - Stefan początkowo nie otrzymuje broni i bardziej stara się przetrwać niż walczy, zaś Baczyńskiemu zostaje powierzona misja specjalna: swoją poezją ma zagrzewać do walki i pracy, nie zaś uczestniczyć w realnej bitwie. Mimo to wojna ukazana jest jako spektakl, z całym atrakcyjnym anturażem bitewnych efektów specjalnych, pokazując otwarcie się polskiego najmłodszego kina na wzorce amerykańskie.

Wszystkie trzy strategie: tak heroicznej atrakcyjności, jak i arthouse’owej dosadności oraz generacyjnej diagnozy jawnie zrywają z dotychczasową tradycją polskiego kina, czerpiąc z kultury i kinematografii zachodniej. Polscy twórcy średniego pokolenia odkryli na nowo temat seryjnych morderców, intryg, kryminału, śmierci - motywu o jednak odmiennym obliczu niż to nakreślane przez najmłodszą generację reżyserów. Reprezentacje zabijania w ich kinie wynikają z westernizacji narodowej kinematografii, inspiracji zagranicznym kinem autorskim, w których śmierć dużo częściej pojawiała się bez gorsetu koniecznej konwencji gatunkowej. 
Twórcy urodzeni i dorastający w latach osiemdziesiątych chcą mówić o świecie im najbliższym, nie unikając diagnozowania generacyjnych problemów i kreślenia pokoleniowych portretów, posługując się przy tym językiem im bliskim. Ten zaś jest mocno zanurzony w formie, przesiąknięty narracyjnymi wzorcami amerykańskiej kultury i estetyką kanonizowaną na międzynarodowych festiwalach filmowych, niewystępującymi dotąd na polskim gruncie. Przyglądając się reprezentacjom zabijania w najmłodszym kinie, możemy więc sporo powiedzieć o świecie ich twórców - zmaterializowanym i zglobalizowanym, budującym przy tym zupełnie nowe relacje i wartości społeczne. Tematycznym novum jest śmierć bez uzasadnienia, brutalna i gwałtowna, odarta z heroicznego kontekstu. Człowiek nie ginie w imię zasad, tym bardziej za własne przekonania czy postawę.

Co ciekawe, mimo obrazu świata zglobalizowanego nie jest on uniwersalny czy oderwany od rodzimego kontekstu. Choć dzisiejsze kino wojenne przestało zadawać głębokie uniwersalne pytania o człowieczeństwo czy sens historii, które były domeną m.in. powojennych filmów Polskiej Szkoły, to nadal jednoznacznie gloryfikuje bohaterów. Śmierć stanowi podstawowy budulec współczesnego patriotyzmu, zaś jego immanentnie wiszące nad bohaterami widmo - polski martyrologiczny los i fatum. Także pozostałe dwie strategie wyraźnie osadzone są w polskich realiach społecznych: zarówno kino generacyjnej diagnozy, portretujące współczesne realia młodych ludzi, jak i czerpiące z zachodnich wzorców filmy arthouse’owej dosadności obrazują konkretne klasy społeczne, co często pozostaje nie bez znaczenia dla rozwoju fabuły. Niektóre z filmów, jak Plac zabaw, odnoszą się do tego tematu bardzo bezpośrednio, inne, jak Obietnica, rysują tylko społeczny kontekst, jednak nie mamy wątpliwości, że każda z tych historii mogła wydarzyć się tuż po sąsiedzku.

\section{Bibliografia}

Chapman, J. (2008). War and film. London: Reaktion Books LTD.

Janion, M. (1991). Projekt krytyki fantazmatycznej. Szkice o egzystencjach ludzi i duchów. Warszawa: PEN.

Kołodziej, A. (2013). Mowa w (s)tarciu z pismem. Slam poetycki jako przykład symbiozy tekstu i wydarzenia. W: E. Bal, W. Świątkowska (red.), Performans, performatywność, performer. Kraków: Wydawnictwo Uniwersytetu Jagiellońskiego.

Lubelski, T. (2015). Historia kina polskiego. Twórcy, filmy, konteksty. Kraków: Universitas. Socha, J. (2017). Uciec z powstania. Dwutygodnik, 7/138. Pobrane z: http://www.dwutygodnik.com/artykul/5360-uciec-z-powstania.html.

Syska, R. (2003). Film i przemoc. Kraków: Rabid.

Szczekała, B. (2014). Nowe kino powstańcze? Ekrany, 5/21, s. 46-49. 
Napiórkowski, M. (2016). Powstanie umarłych. Historia pamięci 1944-2014, Warszawa: Wydawnictwo Krytyki Politycznej.

Urbańska, M. (2017). Historia na ekranie: od faktu do fikcji. Sposoby reprezentacji przeszłości i konstrukcji postaci w polskich filmach o historii najnowszej powstałych po 2010 roku. Media-Kultura-Komunikacja Społeczna, 2/13, s. 9-24. 